Esta publicación cientifica en formato digital es continuidad de la revista impresa ISSN-Versión Impresa 0798-1406 / ISSN-Versión on line 2542-3185Depósito legal pp
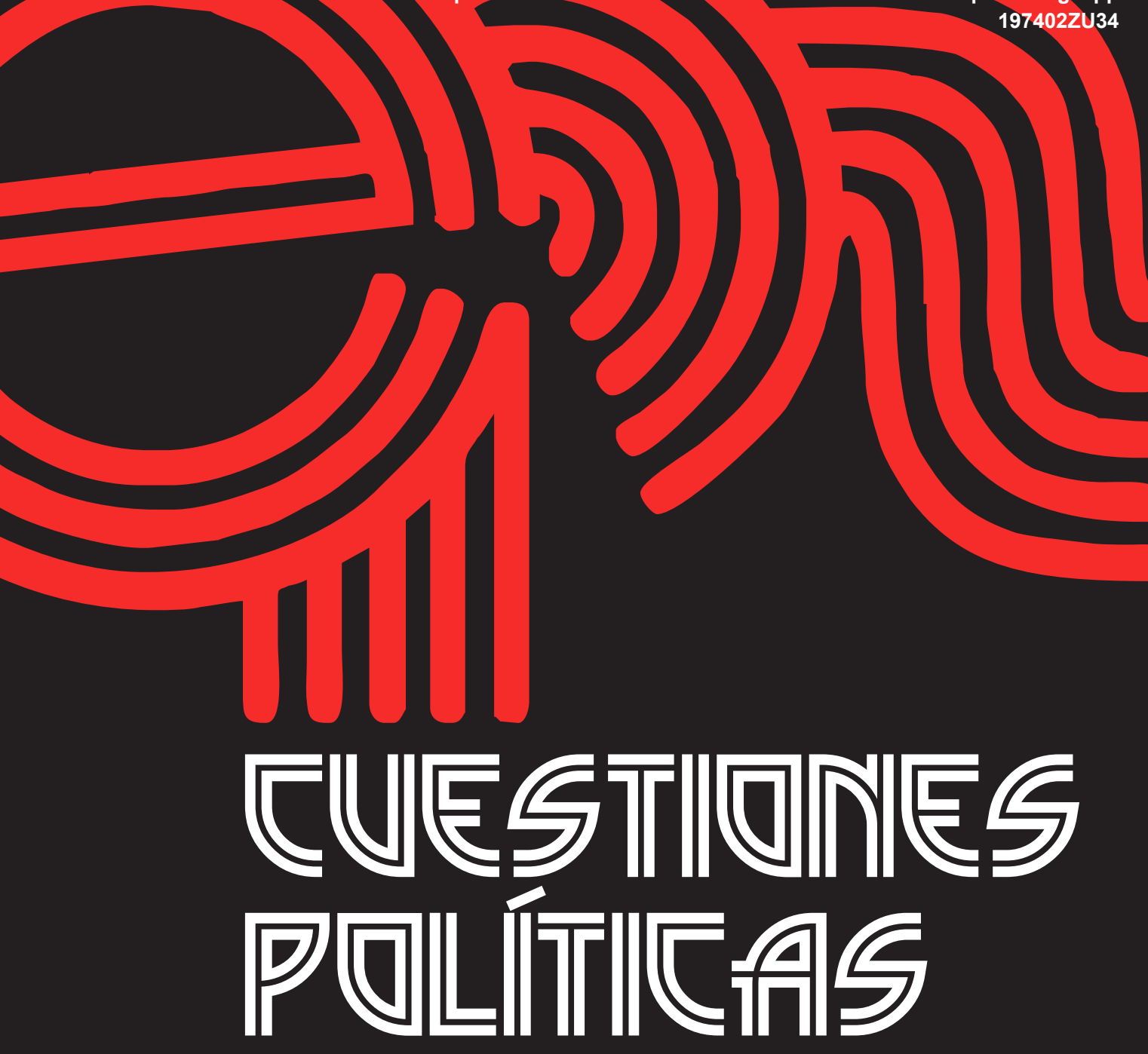

Instituto de Estudios Políticos y Derecho Público "Dr. Humberto J. La Roche" de la Facultad de Ciencias Jurídicas y Políticas de la Universidad del Zulia Maracaibo, Venezuela
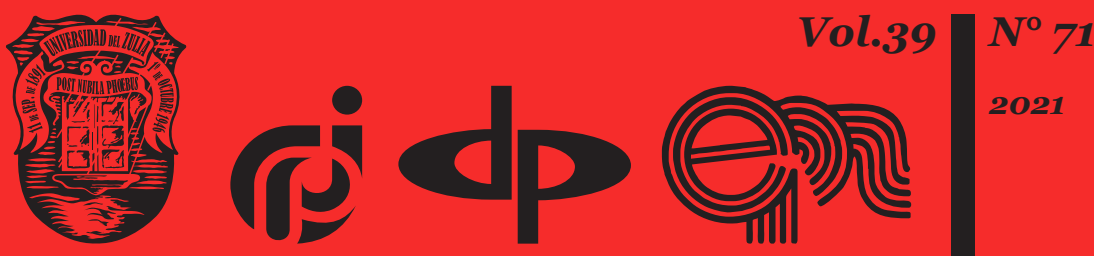


\title{
Constitutional foundations and principles of the formation of a sovereign, secular, and democratic state in India: history and modernity
}

\author{
DOI: https://doi.org/10.46398/cuestpol.3971.38
}

\author{
Artem Arturovich Serdyukov *
}

\begin{abstract}
The purpose of the research was to study the fundamental provisions of the Constitution of India and the amendments made to it, which regulate the constitutional foundations and principles of the formation of a sovereign, secular, and democratic state. In addition, the article discusses the constitutional provisions relating to the acquisition of independence, the freedom of India, the formal establishment and consolidation of the fundamental rights and freedoms of its citizens and the abolition of the institution of untouchability. The study of the role and importance of the political and legal views of the leader of the national liberation movement, the philosopher and jurist Mohandas Karamchand Gandhi in shaping the constitutional foundations and state structure of India is of some interest. The author used a complex of scientific methods to achieve the objective. It is concluded that the achievement of India's political independence, the declaration of equal rights and freedoms and the abolition of the untouchable caste in the state Constitution, is a significant contribution to the development of this country and a rapid step in increasing India's
\end{abstract} importance in the world.

Keywords: democracy; society; citizen; rights and freedoms; equality.

North Caucasus Federal University, Stavropol, Russia. ORCID ID: https://orcid.org/oooo-ooo16508-4071 


\section{Artem Arturovich Serdyukov \\ Constitutional foundations and principles of the formation of a sovereign, secular, and democratic \\ 634 state in India: history and modernity \\ Fundamentos constitucionales y principios de la formación de un estado soberano, laico y democrático en la India: historia y modernidad}

\section{Resumen}

El propósito de la investigación fue estudiar las disposiciones fundamentales de la Constitución de la India y las enmiendas realizadas a la misma, que regulan los fundamentos constitucionales y los principios de la formación de un estado soberano, laico y democrático. Además, el artículo analiza las disposiciones constitucionales relativas a la adquisición de la independencia, la libertad de la India, el establecimiento formal y la consolidación de los derechos y libertades fundamentales de sus ciudadanos y la abolición de la institución de la intocabilidad. El estudio del papel y la importancia de las opiniones políticas y legales del líder del movimiento de liberación nacional, el filósofo y jurista Mohandas Karamchand Gandhi en la formación de los fundamentos constitucionales y la estructura estatal de la India es de cierto interés. El autor utilizó un complejo de métodos científicos para lograr el objetivo. Se concluye que el logro de la independencia política de la India, la declaración de igualdad de derechos y libertades y la abolición de la casta intocable en la Constitución del estado, es una contribución significativa al desarrollo de este país y un rápido paso en el aumento de la importancia de la India en el mundo.

Palabras Clave: democracia; sociedad; ciudadano; derechos y libertades; igualdad.

\section{Introduction}

The formal definition, proclamation, and direct implementation of the principle of a mixed economy with active participation and the possibility of regulation by the state, the synthesis of religious Indian institutions with institutions that arose as a result of the formation and development of the branch of constitutional law, and the implementation of the state function to maintain universal peace and international security, considering the priorities and state of the modern Indian state determine the relevance and significance of studying the genesis of the constitutional structure of India and modern legislative regulation of the foundations of its constitutional system.

In the process of studying the genesis of the constitutional principles of India's statehood, we consider it necessary to note that the Constitution of India was adopted on November 26, 1949, two years after the declaration of independence from British colonial rule. The document was officially published on January 26, 1960 and is valid considering the changes made. 
The Constitution is the supreme law of the state, regulating the main directions of its activities, the mechanism (apparatus) of the state, the powers of state bodies, and the fundamental rights and freedoms of its citizens.

The Constitution of India is currently the most extensive basic law of the state in the world, published using Hindi and English, which has the highest legal force concerning the system of legislative acts of the state. According to a professor at Oxford University, J. Insert (2012), the creators of the basic law of India were able to accumulate in it the positive aspects of the international constitutional experience of countries such as the USA, UK, USSR, Canada, Australia, and many others.

\section{Methods}

The methodological basis of this research was an original universal dialectical method of cognition. In addition, the following scientific methods were used to fully achieve the purpose of the presented article: historical, statistical, formal-legal.

We also used the method of comparative analysis of various views on the priority of customary law in the regulation of public and state life in India and on the importance of constitutional provisions in the process of forming a sovereign, secular, and democratic Indian state, which allows identifying the qualitative features of the basic law of the state and formulating its significance at the present stage of development of society and the state in India.

\section{Results}

Let us consider the points of view of statesmen and leading jurists on the role and significance of the adoption of the Constitution, the formation of constitutional foundations on the process of becoming a sovereign, secular, and democratic state in India.

In this regard, we consider it necessary to investigate the well-founded position of Gabriel Foster, who notes that the adoption of the Constitution of India was not just a huge step on the historical path of the formation and development of its independent statehood. It was a total secularization of its public and state life, the formal consolidation of the legal status of the individual, and the proclamation of his/her freedom from the varnacaste system. It was incredibly significant progress of the personal system of Hindu law, the formation of an independent state, and a free society (Foster, 2007). 


\section{Artem Arturovich Serdyukov 636 \\ Constitutional foundations and principles of the formation of a sovereign, secular, and democratic}

Supporting the importance of the basic law of the state of India, R. Shatropp pointed out that the Constitution of 1950, together with the changes and amendments of 1976, represents for India and every individual Hindu a door to integration on a global scale. It is a painful transition from traditionalism to the norms of law and legislation that considers the unconditional religious way and historical features of the state (Tharoor, 2018).

Pointing out the significance of the amendments made to the Constitution of India, we consider it appropriate to study the 42nd amendment to the basic law of the state, published in 1976, under which India was recognized as a sovereign, social, and secular democratic republic. Despite the formal establishment of the above-mentioned status of the state, the question of how secular the state can be considered in India is debatable at present. Many authors, well-known jurists, and public and state figures note the actual impossibility of recognizing India as a secular state due to the significant influence of religious norms and traditions on the regulation of an individual's life, on his/her worldview, rooted for several centuries, and the unshakable way of society as a whole.

Adhering to a similar point of view, the famous professor of the Delhi University in the field of law, V. Luthera, points out in his works that India has never been a secular state, neither before the adoption of the Constitution and amendments to it, nor after, and what is most interesting it can hardly ever become such. Religion, society, and the state in it represent one indivisible whole, in which the latter two parts repel and live according to the norms of the former, which have been permeating them for centuries, determining and directing. The fact that the adoption of the Constitution and amendments to it makes it secular is, in my opinion, reckless, showing only the strengthening of the role of the state in regulating public life and nothing more (Luthera, 1964).

Agreeing with the opinion of V. Luthera, N. Lindton, professor of constitutional law, focuses on the fact that by adopting the Constitution, it is impossible to change the state itself in an instant, the foundation of which throughout its historical development was the norms of customs and traditions. Therefore, the recognition of a secular character is mostly at least declarative, formal in nature, after all, the role of religion is perfectly understood and realized in the life of the society, state, and individual in India, regardless of whether the state establishes a certain status and order (Lindton, 1972).

A similar position is held by Western Professor D. Smith (1967), arguing that India, by its nature, cannot in principle be a secular state in the format of currently and previously existing public and state relations. 
The desire of India to be recognized as a secular state contradicts in its essence not only the very historical path of Indian civilization, where religion and the norms of traditional law were of predominant importance but also the political worldview of neighboring states, which is also an important factor that cannot be ignored.

The establishment and recognition of the constitutional principles of sovereignty, democracy, and a secular state, according to R. Khorny, is the result of the assimilation of Western ideas and approaches that are unacceptable for traditional India. In no way they affect the development of its statehood: India itself is original and special, therefore Western innovations in its legislation are not able and should not affect its path and especially eradicate the original, traditional that allows its dharma to exist (Khorny, 2015).

Refuting the above arguments, P. Gajendragadkar believes that with the adoption of the Constitution of India, it acquires the shades of a secular state. This occurs not by the fact of the entry into force of the basic law of the state and amendments to it, but consistently, gradually, going through a complex long path of transformation of the religious consciousness of Hindus, recognition of the state itself, its mechanism, the possibility of democratic governance, and the consolidation of rights and freedoms in contrast to the imposed colonial control and management of England (Gajendragadkar, 1971).

Therefore, at the initial stage, there is a recognition of the state as such, awareness of its independence and freedom, a change not only in the consciousness of representatives of society but also the existence of legal consciousness. It represents a new stage in the development of statehood in India and its integration into the international community as a full-fledged sovereign, independent, and free subject.

F. Brittner, sharing this point of view, emphasizes at the same time the synthesis and absolute harmony between the constitutional foundations and the religious adherence of the Hindus. The scholar points out that the recognition of India as a free and secular state, as well as the recognition of the freedom and rights of all representatives of the varna-caste system, does not diminish the role and significance of religious dogma, which will forever remain in the heart and consciousness of absolutely every Hindu (Brittner, 1984).

However, in the process of studying the constitutional foundations and principles of the formation of a sovereign, secular, and democratic state in India, we consider it necessary to point out the importance of the political and legal views and policies of the leader of the national liberation movement, the great statesman and reformer, philosopher, and jurist Mohandas Karamchand Gandhi. 


\section{Artem Arturovich Serdyukov 638 \\ Constitutional foundations and principles of the formation of a sovereign, secular, and democratic}

All of Gandhi's state activities determined and contributed to the liberation of India from the colonial rule of England and the formation of a free, secular, and independent democratic state. Through the unification of Hindus and Muslims, Gandhi promoted the establishment of religious tolerance, the unification of members of Hindu society, and the recognition of each of them as free and full-fledged citizens of India.

Moreover, Gandhi (1958) subjected the representatives of the religious orthodox direction to reasonable sharp criticism from rationalistic and moral-ethical grounds abandoning the role of the sacred sources of Hinduism, calling for establishing and verifying their truth and then throwing out forever everything that does not correspond to reality, the rationalistic principle and the norms of morality, paying special attention to the prescriptions that establish and support early marriages, women's inequality, suttee, the boundaries of the varna-caste system.

Thus, without abandoning the meaning and role of Hinduism, but directly interpreting its position, Gandhi (1957) denied the existing hierarchical structure of society with an inherent differentiation into varnas and castes. In his political and legal doctrine, Gandhi justifies the thesis that the varnacaste structure of Hindu society has never been a necessary natural organic part of Hinduism while drawing an interconnected and conditioned parallel between the hierarchy of the caste structure of society and the institution of «untouchability», the fight against which he recognized as the fundamental and primary function of the state.

Gandhi rightly noted that Krishna has always instructed that a real Bhakti, neither in his thoughts nor in his actions, will never allow any distinction between an ordinary dirty scavenger and a Brahman. Therefore, there is no place for the institution of untouchability in Hinduism (Gandhi, 1959).

With his views, principles, life example, and dedication, Gandhi led India to gain independence, establish equality and freedom, and consolidate basic natural and positive rights. We would like to pay special attention to the synthesis of the provisions of Hinduism and its argumentation in the political and legal concept of the leader of the national liberation movement. Gandhi managed to convey to everyone the meaning of the religious tenets of Hinduism, the belief in the possibility of acquiring freedom, both state and personal. Gandhi's methodology is his life example, way of thinking, consciousness, and sincere sacrifice in the name of India and every Hindu. His direct contribution to the adoption of the Constitution, the acquisition of independence of India, and the codification and unification of Hindu legislation is invaluable.

Highlighting the role of Gandhi in the development of Indian statehood on the principles of freedom, equality, and democracy, J. Nehru (1964: 94) noted that: 
we must always hold on to the anchor of the exact unshakable established and generally accepted objective knowledge, reality, verified by reason, and most importantly by experience, practice, which Gandhi revealed and presented to the Hindu society, giving and explaining to every Hindu, regardless of his affiliation and status (1964: 94).

The author repeatedly emphasized in his speeches that the political and legal principles formed by Gandhi, his very philosophy, permeated with the faith of a true Hindu in synthesis and rational harmony, are combined with legal education, practical skills, scientific knowledge, and empirical experience of a statesman, which in absolute meaning allow giving India and every individual Hindu freedom and independence (Husein, 1978).

\section{Discussion}

Despite the significant influence of religious norms and traditions on the consciousness and worldview of Hindus, the adoption of the Constitution contributed to the development of the statehood of India, the consolidation of the rights and freedoms of its citizens, and the proclamation of an independent sovereign secular state.

The religious dogma of Hinduism plays a significant role in the regulation of public and state relations in India, historically forms the way of life, hierarchical structure, norms of behavior, and much more. In our opinion, it is impossible to deny the role of religion and customary law in the establishment and formation of statehood since the above-mentioned aspect historically acts as a structural element of the consciousness, worldview of every Hindu, and an integral part of society and the state.

The provisions of Hinduism and the norms of customary law have proved the ability and effectiveness of social and state regulation for a long time and have shown the possibility of harmonious coexistence with the norms of positive law.

We believe that the adoption of the Constitution and the codification of Hindu law does not detract from the role and importance of Hinduism and customary law but expands the subjective rights, obligations, and opportunities of Hindus, giving them freedom and equality in an independent sovereign state.

\section{Conclusion}

We analyzed the significance of Mohandas Karamchand Gandhi, the leader of the national liberation movement of India, in gaining independence from the colonial rule of England, and the subsequent adoption of the 


\section{Artem Arturovich Serdyukov \\ Constitutional foundations and principles of the formation of a sovereign, secular, and democratic 640 state in India: history and modernity}

Constitution, reflecting his political and legal views, and codification and unification of Hindu legislation. We consider it necessary to note that, when studying the constitutional foundations and principles of the formation of India, Part 3 of the Indian Constitution is of considerable interest. It is devoted to the fundamental rights of Indian citizens, equal employment opportunities, as well as protection of some subjective rights concerning freedom of speech outside of religion.

We consider it relevant to note the prohibition of discrimination based on caste, religion, race, and gender, provided for in article 15 of the Constitution of India. When establishing the prohibition of discrimination, the legislator, first of all, had in mind representatives of the untouchable caste class, restrictions to which were distributed both on a caste and religious traditional basis, and were carried out on a racial basis.

Investigating the issue of the institution of untouchability in the constitutional foundations of India, it is necessary to refer to the provisions of article 17 of the Constitution. It includes the declarative formal abolition of the existing untouchability and its practice in any manifestations and the actual prohibition of the use and indication of any legal restrictions based on untouchability, which in turn were recognized and sanctioned by the state as crimes strictly punishable by law (Sen, 1976).

The above-mentioned articles of the basic law of India, as well as the codified normative legal acts supplementing them, and judicial practice have had a significant impact on the formation and development of the personal law branch, creating the constitutional foundations and principles for the reform of personal legal systems.

In this connection, the norms of personal law had to comply with generally accepted public order, morality, norms of morality and universal public health (Harrow, 2005), as well as, accordingly, other provisions of Part 3 of the Indian Constitution, which also provided an opportunity to make any innovations and changes by the legislative method.

This possibility was provided for by the provisions of article 246 of the Constitution, in list 3 of annex 7 of which the issues of regulating the institution of marriage, divorce, probate, minors, the united family, and the possibility of dividing it, that is, listing those areas of public relations that were regulated by the norms of personal law, were, in turn, referred to the general joint competence of the union and the states.

Thus, in the process of studying and analyzing the fundamental principles of the formation and development of a sovereign, secular, and democratic state in India, we concluded that political and legal views, their direct active implementation in Gandhi's state activities, in particular, the reformation of the caste system in public the structure of India, the statement about the unequal and unfair position of the untouchable caste, the need to provide 
equal rights, freedoms, and opportunities for all members of society and the state, the establishment of gender equality, and the prohibition of early marriage were the prerequisites for the adoption of the 1950 Constitution.

The adoption of the basic law of the state and several above-mentioned amendments to it determines a new historical stage in the formation of an independent sovereign democratic state of India. Despite the criticism of several provisions of the Constitution, justified by the prevailing importance of traditions and customs in the regulation of public and state life, the actual impossibility of implementing constitutional principles in the real life of India, we believe that the acquisition of political independence and the consolidation of democratic principles is a significant progressive step both for the state itself and for its citizens.

\section{Bibliographic References}

BRITTNER, Filipp. 1984. The State India. Press. New York, USA.

FOSTER, Gans. 2007. Political Development of India. Panos. London, UK.

GAJENDRAGADKAR, Pralhad Balacharya. 1971. Secularism and the Constitution of India. University of Bombay. Bombay, India.

GANDHI, Mahatma. 1957. The Nation's Voice. Navajivan Publishing House. Ahmedabad, India.

GANDHI, Mahatma. 1958. Answers to Questions In: Collected Works of Mahatma Gandhi. Publications Division, Ministry of Information and Broadcasting, Government of India. Delhi, India.

GANDHI, Mahatma. 1959. India of My Dreams. Navajuvan Publishing House. Ahmedabad, India.

HARROW, Robert. 2005. No Place to Hide. Simon and Schuster. New York, USA.

HUSEIN, Assur. 1978. Law and Development of India. Babel. New Delhi, India.

INSERT, Jhon. 2012. Constitutions of the countries of the world: a comparative analysis. The University of Oxford. London, UK.

KHORNY, Robert. 2015. Modern India. Vikas. New Delhi, India.

LINDTON, Nil. 1972. Politics in India. Boston University. Boston, USA. 
LUTHERA, Ved Prakash. 1964. The Concept of the Secular State and India. Oxford University Press. London, UK.

NEHRU, Jawaharlal. 1964. Homage. Publications Division, Ministry of Information and Broadcasting, Government of India. Delhi, India.

SEN, Lins. 1976. "Modernization, Development and Innovation in Non-Western Societies: a conceptual re-evaluation” In: Zeitschrift für ausländische Landwirtschaft: Sozialökonomik, Betriebswirtschaft, Landbautechnik. Vol. 15, pp. 365-380.

SMITH, Donald Eugene. 1967. India as a Secular State. Princeton University Press. New Jersey, USA.

THAROOR, Shashi. 2018. The Great Indian Novel. Arcade. New York, USA. 

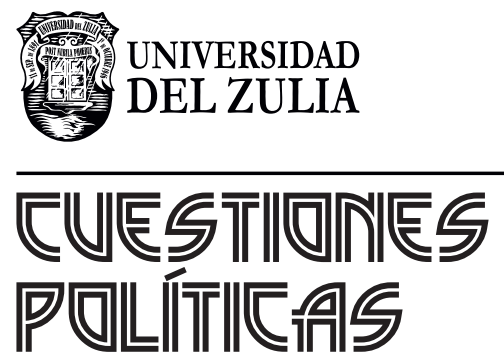

Vol. 39 N $^{\circ} 71$

Esta revista fue editada en formato digital y publicada en diciembre de 2021, por el Fondo Editorial Serbiluz, Universidad del Zulia. Maracaibo-Venezuela 